\title{
SIMULATION OF THE PRODUCTION PROCESS OF BIODIESEL FROM JATROPHA CURCAS OIL
}

\author{
M.F. LABORDE ${ }^{\dagger, \ddagger}$, L.I. ORIFICI ${ }^{\ddagger}$, J.A. BANDONI ${ }^{\S}$, M. SERNA-GONZALEZ* \\ J.M. PONCE-ORTEGA*, M.C. GELY ${ }^{\ddagger}$ and A.M. PAGANO ${ }^{\ddagger}$ \\ †CONICET, Argentina. \\ $\ddagger$ Dto. de Ing. Química, Univ. Nac. Centro de la Prov. Bs. As., 7400 Olavarría, Argentina \\ §PLAPIQUI-CONICET-UNS, Bahía Blanca, Argentina. \\ * UMSNH, Morelia, México. \\ apagano@fio.unicen.edu.ar
}

\begin{abstract}
In this paper was assessed the potential of biodiesel production from Jatropha curcas oil. The proposed process was simulated in the software Aspen Plus ${ }^{\mathrm{TM}}$ involving the stages of trans-esterification reaction, methanol recovering, purification of the obtained methyl esters, catalyst removing, purifying of glycerol and the energy integration through heat exchange networks (HEN). The biodiesel process was carried out through the catalytic reaction of transesterification of Jatropha oil with methanol using a molar ratio of methanol oil of $6: 1$, and with $1 \% \mathrm{w} / \mathrm{w}$ of $\mathrm{NaOH}$ (related to oil mass) as catalyst. Under these conditions, it is technologically feasible to carry out the production of biodiesel. With energy integration through the synthesis of HENs, reductions of $8.5 \%$ and $6.5 \%$ of hot and cold utilities were achieved. This way, the utility cost decreases $7.2 \%$. The net present value (NPV) for the integrated process was $7.3 \%$ higher than the one corresponding to the non-integrated process under the same production conditions.

Keywords-Simulation; energy integration; optimization; biodiesel; biofuels.
\end{abstract}

\section{INTRODUCTION}

Biodiesel is a safe, renewable, non-toxic, biodegradable and much less polluting fuel for the environment than conventional diesel (Chakraborty et al., 2015; GomezCastro et al., 2015; Khang et al., 2018; López-Díaz et al., 2018). Therefore, even though the cost of biodiesel is greater than the diesel oil, many governments support the development of this biofuel considering mainly environmental aspects (Elms and El-Halwagi, 2010). Biodiesel can be obtained through the catalytic reaction of transesterification of triglycerides with alcohols of short chain, generally at temperatures near the boiling point of the alcohol. For example, Fig. 1 shows the stoichiometry of the catalytic reaction of transesterification of triglycerides with methanol (Zhang et al., 2003). The best range of temperature to obtain the major performance of the biodiesel production is between 50 and $70^{\circ} \mathrm{C}$ (Foon et al., 2004), employing concentrations of the alkaline catalysts of 0.5 to $1 \% \mathrm{w} / \mathrm{w}$ (related to the oil mass), and using molar ratios of oil/alcohol between 1/5 and 1/10 (Kapilakarn and Peugtong, 2007), being the most recommendable the rate 1/6 (Demirbas et al., 2011).

The raw material cost is a fundamental economic factor to the viability of biodiesel production. According to

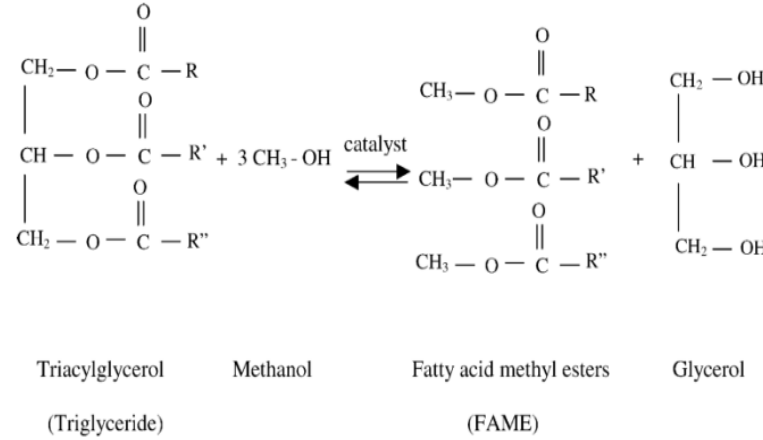

Fig. 1: Scheme of the catalytic transesterification reaction of triglycerides (vegetable oils) with methanol to produce biodiesel (FAME, fatty acid methyl esters) and the co-product glycerol (Zhang et al., 2003).

the literature, approximately $70-95 \%$ of the total production cost of biodiesel is associated to the raw material costs (Demirbas et al., 2011; Kuo et al., 2015).

Currently, over 95\% of global biodiesel is produced from edible oils (Demirbas et al., 2011), mainly rapeseed, sunflower, soybean and palm (Santacesaria et al., 2012). However, there is a growing concern about the competition between the use of these raw materials for the production of biodiesel against its use as food (Demirbas et al., 2011), not only from the nutritional point of view, but also regarding the use of land for cultivation (Santacesaria et al., 2012).

Current trends converge to the need for the use of non-edible oils to biodiesel production (Demirbas et al., 2011; Ahmed et al., 2015). These vegetable oils can be produced from jatropha, karanja, snuff, Mahua, neem, rubber, seamango, castor, cotton, etc. And from these raw materials, jatropha oils, karanja, Mahua and castor are the most commonly used for the synthesis of biodiesel (Banković-Ilić et al., 2012). Jatropha curcas oil is one of the best raw materials for producing biodiesel due to its inedible property and thus its production does not compete with food crops (Guo et al., 2011; Luu et al., 2014). It has a very high potential of biodiesel production per hectare of cultivated Jatropha, not competing with food grains due to their high toxicity because the seed contains alkaloids curcin and phorbol esters (Falasca and Ulberich, 2008; REDPA, 2009).

Moreover, it is considered that Argentina has suitable conditions for growing Jatropha (Renner et al., 2008). The best land for cultivation can be found in the prov- 
inces of Misiones, Corrientes, north of Santa Fe, Formosa, Chaco, Tucuman, north of Santiago de Estero, north of Salta, Jujuy south and southwest of La Rioja and Catamarca (Falasca and Ulberich, 2008). In a recent paper by Ahmed et al. (2015), they obtained an oil conversion of approximately $96.09 \%$ for the production of biodiesel from Jatropha curcas oil by the reaction of transesterification with alkaline catalysis, and from analytical techniques, there was established that this biodiesel meets the ASTM quality standards. Brittaine and Lutaladio (2010) estimated for the year of 2015 a world-wide area planted with Jatropha of 13 million hectares. Jatropha curcas seeds with an oil yield between 35-40\% (Teodoro et al., 2017) produce approximately $1800 \mathrm{~L}$ of oil per hectare (Castro Gonzáles, 2012).

From the point of view of the biodiesel production process, energy efficiency is an extremely important aspect. A tool for achieving this goal is the use of heat exchange networks (HEN) for energy recovery. Pinch technology is one of the best tools that can be used for the design of an optimal heat exchange network (HEN). It was first used in 1982-1983 for the design of heat exchanger networks in individual processes (Linnhoff and Flowe, 1982; Linnhoff and Hindmarsh, 1983). The use of heat exchange networks compared with the use of external utilities (heating and cooling), decreases energy consumption, which is reflected in lower operating costs (Laborde et al., 2014a,b). This HEN utilization strategy has been successfully implemented in the production of biodiesel from microalgae (Sánchez et al., 2011) and in a soy-based biorefinery (Granjo et al., 2017).

The Aspen Energy Analyzer ${ }^{\mathrm{TM}}$ software is a computational tool to obtain the pinch targets, the minimum requirements for external utilities and to simulate the network design to obtain the optimal heat exchange, determining the required heat transfer areas for each exchanger. Moreover, the Aspen Plus ${ }^{\mathrm{TM}}$ software can simulate the process of transesterification with and without heat exchange network to analyze its characteristics and the effects of different operating conditions.

This paper presents a simulation-based approach for the biodiesel production process considering an alkaline transesterification of Jatropha oil with methanol, which is implemented in the Aspen Plus ${ }^{\mathrm{TM}}$ software. We worked from the model developed by Zhang et al. (2003) for virgin vegetable oil composed entirely of triolein. Later, the model is adapted for Jatropha curcas oil characterized by its corresponding triglycerides. Subsequently, a preliminary energetic integration between main streams of the process is applied to the latter model and a differential cost analysis is performed to evaluate the proposed alternatives (Dutta, 2004; Horngren et al., 2006; Rajasekaran and Lalitha, 2011). From this analysis, it is intended to show the feasibility of producing biodiesel from an alternative raw material considering the efficient use of energy in the process.

\section{METHODOLOGY}

The simulation of the global process was performed using the Aspen Plus ${ }^{\mathrm{TM}}$ v7.2 software, a recognized and powerful tool for engineering design (Erdmann et al., 2012). The process developed by Zhang et al. (2003) from virgin vegetable oils (described as pure triolein) was developed in Aspen plus under similar conditions. The process was based on the alkali catalyzed reaction of transesterification of the oil with methanol using a molar ratio of 6:1 (methanol:oil) and a fraction of catalyst of $1 \%$ w/w of $\mathrm{NaOH}$ related to oil mass. The oil feed to the process was set as $0.29 \mathrm{~kg} / \mathrm{s}$. The reaction was carried out in a conversion type reactor, where $95 \%$ of conversion in biodiesel is obtained at $60{ }^{\circ} \mathrm{C}$ and $400 \mathrm{kPa}$ (Zhang et al., 2003; West et al., 2008). For different processing units, negligible pressure drops were assumed. The feed to the system was entered at ambient conditions.

Based on the decision tree proposed by Carlson (1996) for the properties estimation, the NRTL (NonRandom Two Liquid) thermodynamic model was used (Zhang et al., 2003). Castillo-Peña et al. (2013) also considered appropriated this model based on the activity coefficients for non-ideal systems. Components as phosphoric acid and sodium sulfate were incorporated as solids, applying the corresponding property estimation approach.

Later, the biodiesel production process was re-designed for the transesterification of Jatropha curcas oil with methanol including process integration through HEN.

Jatropha curcas oil was defined as composed by its majority triglycerides in mass fractions of $12.06 \%$ of tripalmitin, $30.24 \%$ of triolein, $51.64 \%$ of triestearin and $5.27 \%$ of trilinolein, considering the remaining components present in the oil as palmitic acid (Castillo-Peña et al., 2013). The chemical components involved in the process were determined, some of them from the Aspen Plus $^{\mathrm{TM}}$ Library, and others that were not found there (PPP: tripalmitin , SSS: triestearin, LLL: trilinolein, and their corresponding methyl esters: C17:0 methyl palmitate, C19:0: methyl stearate and C19:2: methyl linoleate) were generated as hypothetical components (see Table 1) based on their properties including boiling point (Tb), critical properties (Tc: temperature, Pc: pressure, Vc: volume, Zc: compressibility factor), enthalpy (Hf) and free energy of formation (Gf) (Aca-Aca et al., 2009).

The process was completed by the steps of: i) methanol recovery, ii) recycling the recovered methanol to the feed system, iii) purification of the obtained methyl esters, iv) neutralization of the alkaline catalyst with $\mathrm{H}_{3} \mathrm{PO}_{4}$, v) separation of the generated $\mathrm{Na}_{3} \mathrm{PO}_{4}$, vi) purifying of the byproduct glycerin (Fig. 2).

The analysis of the properties of the biodiesel obtained from Jatropha curcas oil was conducted by comparing the values of empirical correlations with the provisions of ASTM D6751 and the European standard EN14214. The kinematic viscosity, density and cetane number were calculated from the correlations found by Ramírez-Verduzco et al. (2012), and the higher heat power (HHV) was determined using the correlations developed by Demirbas (2008). 
Table 1. Properties of hypothetical components.

\begin{tabular}{|llllllll|}
\hline Property & Units & \multicolumn{6}{c|}{ Component } \\
\cline { 3 - 7 } & & PPP & SSS & LLL & C17:0 & C19:0 & C19:2 \\
\hline $\mathrm{Tb}$ & $\mathrm{K}$ & 804.6 & 825.6 & 819.4 & 581.0 & 601.9 & 595.7 \\
$\mathrm{Tc}$ & $\mathrm{K}$ & 923.4 & 945.2 & 941.3 & 717.6 & 740.2 & 736.2 \\
$\mathrm{Pc}$ & $\mathrm{bar}$ & 3.7 & 3.3 & 3.2 & 12.6 & 11.1 & 10.7 \\
$\mathrm{Vc}$ & $\mathrm{cm} / \mathrm{mol}$ & 2947.9 & 3282.5 & 3219.6 & 1007.1 & 1118.6 & 1097.6 \\
$\mathrm{Zc}$ & & 0.1 & 0.1 & 0.1 & 0.2 & 0.2 & 0.2 \\
$\mathrm{Hf}$ & $\mathrm{kJ} / \mathrm{mol}$ & -2029.8 & -2184.4 & -1498.0 & -710.2 & -751.8 & -522.9 \\
$\mathrm{Gf}$ & $\mathrm{kJ} / \mathrm{mol}$ & -555.2 & -505.8 & -38.8 & -215.1 & -198.6 & -42.9 \\
\hline
\end{tabular}

The HEN was designed by applying the Pinch method (Laborde et al., 2014a,b; Renedo Estébanez and Fernández Díez, 2003a,b; Kemp, 2007). For decision makers, it is recommended to compare at least two alternative projects. In this case, two designs of the biodiesel production process -with and without HEN- are presented. To compare both technological alternatives, a differential economic analysis was conducted (Dutta, 2004; Horngren et al., 2006; Rajasekaran and Lalitha, 2011). The difference between the two processes lies in the heat exchange equipment (capital cost) and in the cost for utilities (operating costs). The evaluation of the capital cost was made using the Eq. (1) presented by Ulrich and Vasudevan (2009)

$$
C_{B M}=C_{P} \quad F_{B M a}
$$

where $C_{B M}$ is the bare module cost (US\$), $C_{P}$ is the purchase cost (US\$) and $F_{B M a}$ is the factor of nude module obtained from the product of $F_{M}$ (material factor) and $F_{P}$ (pressure factor). The coefficient $C_{P}$ and the factors of material and pressure were taken from the work of Ulrich and Vasudevan (2009).

The Aspen Energy Analizer ${ }^{\mathrm{TM}}$ software was used to obtain the areas of the heaters and coolers for the process with and without HEN. The exchangers used in this process were selected of double pipe type due to the small exchange areas (Kern, 1965; Carrizales Martinez, 2011) and the building material is carbon steel. For determining the external utility costs, cooling water and heating steam, used in coolers and heaters, respectively, the Eq. (2) proposed by Ulrich and Vasudevan (2006) was used.

$$
C_{s, u}=a C E P C I+b C_{s, f}
$$

where $C_{S, u}$ is the utility price (US\$/kg for steam and $\mathrm{US} \$ / \mathrm{m}^{3}$ for water), $a$ and $b$ are coefficients, $C_{S, f}$ is the fuel price (US\$/gallon) and CEPCI is the coefficient of actualization costs (Chemical Engineering Plant Cost Index).

For the cooling water (Ulrich and Vasudevan, 2006), Eq. (3) is the relationship used for calculating the coefficient $a$, being the coefficient $b$ equal to 0.003 , both under the condition $0.01 \mathrm{~m}^{3} / \mathrm{s}<q w<10 \mathrm{~m}^{3} / \mathrm{s}$.

$$
a=0.0001+3 \times 10^{-5} q w^{-1}
$$

where $q w$ is the cooling water flow rate.

Eqs. (4) and (5) are used for calculating the coefficients $a$ and $b$ for the heating steam (Ulrich and Vasudevan, 2006):

$$
\begin{aligned}
& a=2.5+10^{-5} \mathrm{~ms}^{-0.9} \\
& b=0.0034 p^{0.05}
\end{aligned}
$$

where $m s$ is mass flow rate and $p$ pressure, for $1 \mathrm{bar}<p$ $<46$ bar and $0.06 \mathrm{~kg} / \mathrm{s}<m s<40 \mathrm{~kg} / \mathrm{s}$.
A cash flow for five years was considered, accounting for the investment in heat exchange equipment, the variable cost equal to the cost of utilities and identical income value for both alternatives. Also, the NPV (net present value), considering a rate of $7 \%$, was determined (Marchetti et al. 2008).

\section{A. Process modeling}

As mentioned above, initially, the alkali-catalyzed process of biodiesel production from virgin vegetable oil simulated by Zhang et al. (2003) was reproduced using the Aspen Plus ${ }^{\mathrm{TM}}$ software. Fig. 2 shows the main streams of raw materials and products for this simulation.

Subsequently, the oil supply process (stream 105) was changed by Jatropha curcas oil as raw material, composed by mass fractions of 0.3024 of triolein, 0.1206 of tripalmitin, 0.0527 of tristearin, 0.5164 of trilinolein and 0.0079 of palmitic acid (Castillo-Peña et al., 2013). As a result, the values for the main streams of the biodiesel process from Jatropha curcas oil were obtained. It was possible add to the initial stream of fresh methanol (101) about $0.031 \mathrm{~kg} / \mathrm{s}$ of recovered methanol (1201) from the separation by G-201 column (Fig. 2), leaving only $0.002 \mathrm{~kg} / \mathrm{s}$ of methanol remaining in the product stream (202). Moreover, catalyst removal occurs by neutralization with phosphoric acid in the unit R201, where water and $\mathrm{Na}_{3} \mathrm{PO}_{4}$ are obtained which then are totally separated in unit X302. Scrubber tower T301 is capable to separate the $99.95 \%$ of the obtained biodiesel of the glycerol by-product, which is entirely obtained in stream 302. In the T-401 column, the biodiesel purification is performed. In this stream 401A, methanol is obtained as vapor. At the bottom stream 402, the unreacted triglycerides are separated. As can be seen, from $0.29 \mathrm{~kg} / \mathrm{s}$ of oil entering in stream 105 may be obtained $0.274 \mathrm{~kg} / \mathrm{s}$ of methyl esters in the stream 401. In this regard, the obtained biodiesel containing higher esters $99 \%$ meets the quality specifications of Resolution No 828/2010 of the Secretaría de Energía, Argentina (InfoLEG, 2010). The glycerin separation is performed in the stream 502. The stream contains $89.4 \%$ of glycerin and $7 \%$ of water, among other components. The glycerin obtained meets with the specifications of crude glycerin (product of transesterification and suitable for further refinements and purification, consisting of separating solids and triglycerides, methanol recovery, water recovery, ion exchange and distillation) (Morales et al., 2010; Posada Duque and Cardona Alzate, 2010; Troncoso et al., 2015).

With a theoretical yield of $10 \%$ in the transesterification process , crude glycerin has 50-60\% pure glycerol, $20-25 \%$ methanol and rests of water, catalyst, soaps, oil residues and alkyl esters, therefore it is necessary to purify the crude glycerin to give it commercial value.

\section{B. Analysis of the quality of produced biodiesel}

There were determined the kinematic viscosity (KV), density (D), higher heating value (HHV) and cetane number (CN) of biodiesel from Jatropha curcas oil using the correlations established by Ramírez-Verduzco et al. 


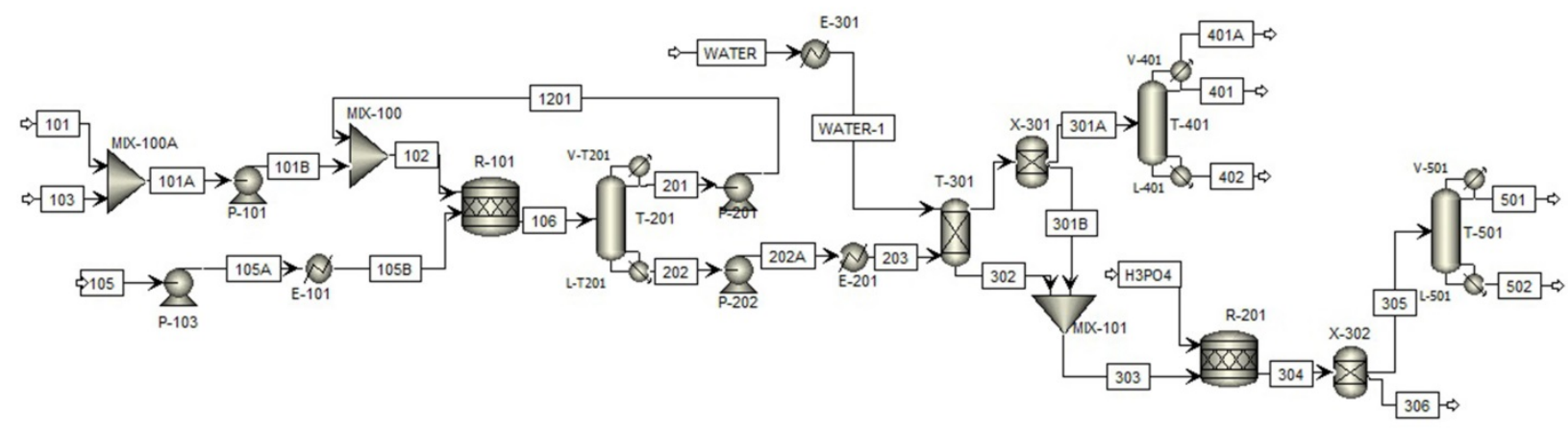

Fig. 2: Flowsheet for the biodiesel process from virgin vegetable oil reproduced in Aspen Plus ${ }^{\mathrm{TM}}$.

(2012) and Demirbas (2008). These values were compared with the provisions of ASTM D6751 and the European standard EN-14214, and also with experimental values reported by Koh and Ghazi (2011), Ong et al. (2011) and Okullo et al. (2012) for biodiesel from Jatropha curcas oil, as Table 2 shows.

The correlations were evaluated from simulation data. The density value evaluated for biodiesel was in the range specified by the European standard EN-14214, which is only $0.3 \%$ higher than the one reported by Koh and Ghazi (2011). The kinematic viscosity was within the range of both standards, still $40 \%$ higher than the one reported by Koh and Ghazi (2011), being close to the values reported by Ong et al. (2011) and Okullo et al. (2012).

The higher heat capacity was similar to the experimental data. The cetane number was higher than the minimum specified by both standards but lower than those reported experimentally. Therefore, the process sets out in this paper allows obtaining a biofuel with properties similar to data reported experimentally, and according to ASTM D6751 and European Standard EN-14214.

\section{Application of HEN}

From the simulation performed using as raw material Jatropha curcas oil, the streams requiring heating and cooling utilities were determined. Then, the pinch method was applied to those streams. Figure 3 show the

Table 2. Comparison of properties of biodiesel from Jatropha

\begin{tabular}{lcccc}
\hline \multicolumn{5}{c}{ curcas. } \\
Property & $\begin{array}{c}\mathrm{D} \\
\left(\mathrm{kg} / \mathrm{m}^{3}\right)\end{array}$ & $\begin{array}{c}\mathrm{KV} \\
\left(\mathrm{mm}^{2} / \mathrm{s}\right)\end{array}$ & $\begin{array}{c}\mathrm{HHV} \\
(\mathrm{MJ} / \mathrm{kg})\end{array}$ & $\mathrm{CN}$ \\
\hline $\begin{array}{l}\text { From } \\
\text { simulation }\end{array}$ & $882.55^{\mathrm{a}}$ & $4.18^{\mathrm{a}}$ & $40.16^{\mathrm{b}}$ & $53.33^{\mathrm{a}}$ \\
$\begin{array}{l}\text { ASTM D6751 } \\
\text { EN 14214 }\end{array}$ & --- & $1.9-6$ & --- & Min. 47 \\
$\begin{array}{l}\text { Koh and Ghazi } \\
(2011)\end{array}$ & $860-900$ & $3.5-5.0$ & --- & Min. 51 \\
$\begin{array}{l}\text { Ong et al. } \\
(2011)\end{array}$ & $2.35-2.47$ & $39.65-41.63$ & $60.74-63.27$ \\
$\begin{array}{l}\text { Okullo } \text { et al. } \\
(2012)\end{array}$ & 871 & 4.8 & 39.23 & 57 \\
\hline
\end{tabular}

${ }^{\mathrm{a}}$ From correlations reported by Ramírez-Verduzco et al. (2012) ${ }^{\mathrm{b}}$ From correlations reported by Demirbas (2008)

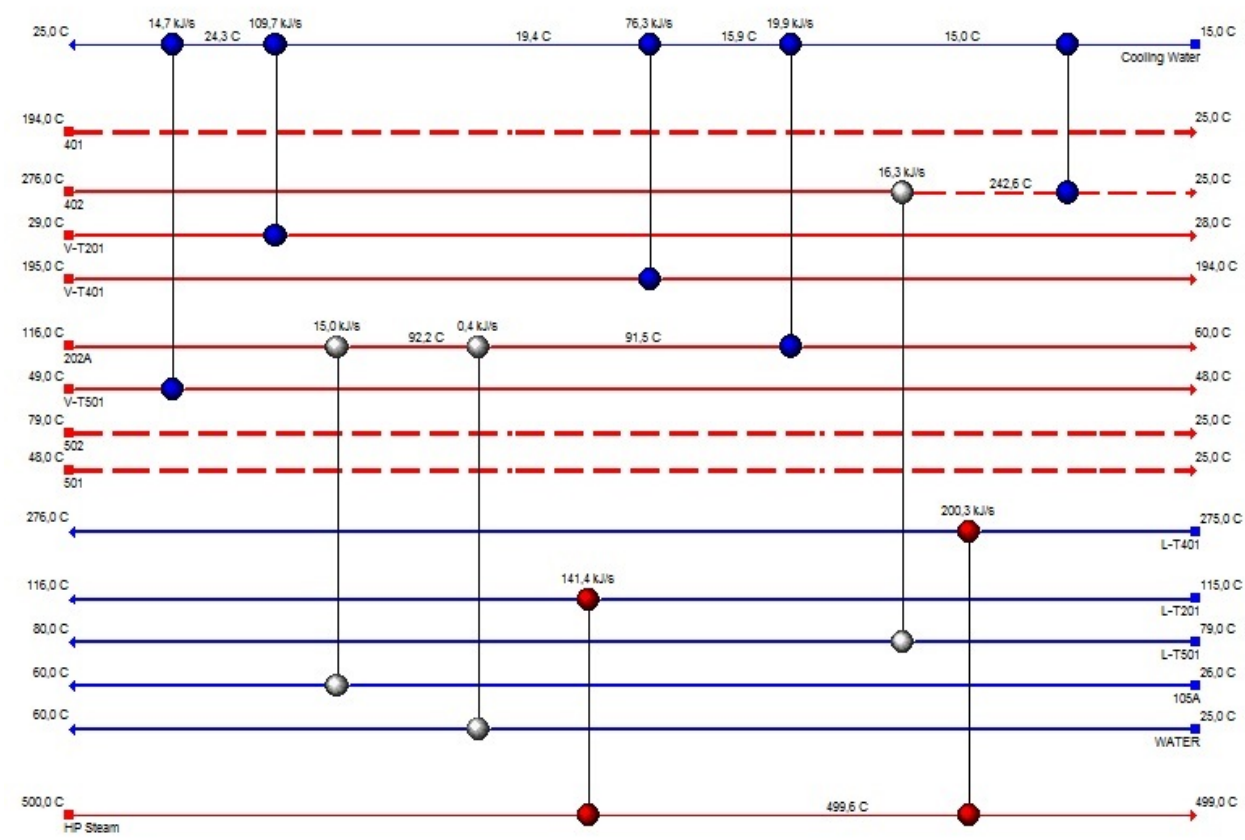

Fig. 3 Characteristics of the streams with external energy requirement. HEN simulated in Aspen Energy Analyzer ${ }^{\mathrm{TM}}$. 
Table 4. Characteristics of the required utilities and equipment.

\begin{tabular}{clcccc}
\hline Process & Equipment & $\mathrm{A}\left(\mathrm{m}^{2}\right)$ & $\mathrm{Q}(\mathrm{kJ} / \mathrm{s})$ & $\mathrm{ms}(\mathrm{kg} / \mathrm{s})$ & $\begin{array}{c}\mathrm{qw} \\
\left(\mathrm{m}^{3} / \mathrm{s}\right)\end{array}$ \\
\hline \multirow{2}{*}{ Without HEN } & Coolers & 6.9 & 236.1 & - & 0.05 \\
& Heaters & 113.3 & 373.5 & 22.2 & - \\
\hline \multirow{2}{*}{ With HEN } & Coolers & 6.5 & 0.2 & - & 0.05 \\
& Heaters & 112 & 341.8 & 20.1 & - \\
& Exchangers & 4 & - & - & - \\
\hline
\end{tabular}

Table 5. Cost of equipment of heat exchange and operation.

\begin{tabular}{clcc}
\hline \multirow{2}{*}{ Process } & \multicolumn{1}{c}{ Equipment } & $\begin{array}{c}\text { Capital Cost } \\
\text { (US\$) }\end{array}$ & $\begin{array}{c}\text { Operating Cost } \\
\text { (US\$/year) }\end{array}$ \\
\hline \multirow{2}{*}{ Without HEN } & Coolers & 47042 & 662583 \\
& Heaters & 174145 & 4599035 \\
\hline \multirow{3}{*}{ With HEN } & Coolers & 28949 & 662583 \\
& Heaters & 171431 & 4221995 \\
& Exchangers & 28949 & - \\
\hline
\end{tabular}

simulation in Aspen Energy Analyzer ${ }^{\mathrm{TM}}$ all the flows available for heat exchange and the obtained HEN. As a result of applying the pinch method, considering a minimum temperature difference $(\Delta \mathrm{Tmin})$ of $10^{\circ} \mathrm{C}$, it was determined that in this case the pinch temperature is $270^{\circ} \mathrm{C}$. The streams involved in the HEN are 202A, 105A, WATER, 402 and L-T501 (Fig. 2). By ensuring a requirement of external utility of 393191.1 W and 199812.4 W in cooling and heating, respectively.

The application of this exchange network has reduced heating utility by $8.5 \%$ and cooling utility by $6.5 \%$. Operating costs were reduced by $7.2 \%$.

As shown in Fig. 3, the network was defined by the exchanges between streams 202A and 105A, 202A and WATER and by last between L-T501 and 402.The stream 105A satisfies the power requirement and stream $202 \mathrm{~A}$ reaches the temperature of $92.2^{\circ} \mathrm{C}$. In the second exchange between 202A (leaving the first exchange at $92.2^{\circ} \mathrm{C}$ ) and WATER, this one satisfies its energy requirement and the 202A stream reaches the temperature of $91.5^{\circ}$ C. Finally, in the last exchange the L-T501 stream satisfies the power requirement and the 402 stream reaches a temperature of $242.6^{\circ} \mathrm{C}$. Process output 401, 402, 501 and 502 do not require cooling utility as they leave the system and will eventually be stored.

\section{Estimation of costs and profitability analysis}

The required utilities for the process without HEN are cooling water $\left(\mathrm{Te}=15^{\circ} \mathrm{C}\right.$, Ts $=25^{\circ} \mathrm{C}$ ) and high pressure steam $\left(\mathrm{Te}=500^{\circ} \mathrm{C}\right.$, Ts $\left.=499^{\circ} \mathrm{C}\right)$. Table 4 shows for the systems with and without network the total exchange areas, the total heat exchanged and the total utilities.

From the above, the cost of equipment is determined by Eq. (1) and utilities with Eq. (2), which are presented in Table 5. The daily price of fuel oil of $1.78 \mathrm{US} \$$ /gallon is considered (Index Mundi,2019) and CE PCI 2018 is 603.1 (Chemical Engineering, 2019). Analyzing Table 5, there is determined that the total equipment cost required by the process with HEN is US\$8142 higher than the project without HEN. However, the utility cost is reduced by $7.2 \%$ annually.

Finally, comparing the NPV of each process (with and without energy integration), it appears that this index results $7.3 \%$ higher in the case of the integrated process, which means a viable project. This result verifies that when introducing a heat exchange network, the initial investment costs in equipment are increased, decreasing the costs of external utilities. This connection between investment costs and operating costs allowed a significant increase in the NPV of the project.

\section{CONCLUSIONS}

The catalytic transesterification of Jatropha curcas oil under the conditions evaluated is technologically feasible for the biodiesel production, and it allows to obtain a biofuel with properties similar to the data reported experimentally, and according to the ASTM D6751 and European standards EN-14214. Through the energy integration, there are achieving reductions by $8.5 \%$ in the heating utility and by $6.5 \%$ in the cooling utility. The total cost of heat exchange equipment for the process of transesterification of Jatropha curcas oil applying the energy integration is US\$ 8142 greater than the one corresponding to the process without energy integration, but the utility cost is reduced by $7.2 \%$ annually. When comparing the NPV of each alternative technology, it is noted that this indicator is $7.3 \%$ higher for the energy integrated process.

\section{REFERENCES}

Aca-Aca, M.G., Campos González, E., Sánchez-Daza, O., López-Arenas, M.T. and Sales-Cruz, A.M. (2009). "Estimación de propiedades termodinámicas de los compuestos involucrados en la producción de biodiesel," Superficies y Vacío, 22, 15-19.

Ahmed, W., Nazar, M.F., Ali, D.S., Rana, U.A. and Khan, S.U.D. (2015). "Detailed investigation of optimized alkali catalyzed transesterification of Jatropha oil for biodiesel production," Journal of Energy Chemistry, 24, 331-336.

Banković-Ilić, I.B., Stamenković, O.S. and Veljković, V.B. (2012). "Biodiesel production from non-edible plant oils,” Renewable and Sustainable Energy Reviews, 16, 3621-3647.

Brittaine, R. and Lutaladio, N. (2010). Jatropha: a smallholder bioenergy crop: the potential for pro-poor development,” 8, Food and Agriculture Organization of the United Nations (FAO).

Carlson, E.C. (1996). "Don’t Gamble with Physical Properties for Simulations," Chemical Engineering Progress, 92, 35-46.

Carrizales Martinez, R. (2011). "Guía para seleccionar intercambiadores de calor,” Tlatemoani, 6, 1-11.

Castillo-Peña, A., Labrada-Vázquez, B.L., Penedo-Medina, M. and Sánchez-del-Campo-Lafita, A.E. (2013). "Simulación del proceso de producción de biodiésel a partir del aceite de Jatropha curcas," Tecnología Química, 33, 125-142.

Castro Gonzáles, N.F. (2012). "Food security and biofuels: A case study of Jatropha curcas in Bolivia," Int. J. of Thermal \& Environmental Engineering, 4, 109-116.

Chakaborty, R., Das, S. and Bhattacarjee, S.K. (2015).“Optimization of biodiesel production for 
Indian mustard oil by biological tri-calcium phosphate catalyst derived from turkey bone ash,” Clean Technologies and Environmental Policy, 17, 455463.

Demirbas, A. (2008). "Relationships derived from physical properties of vegetable oil and biodiesel fuels," Fuel, 87, 1743-1748.

Demirbas, M.F., Balat, M. and Balat, H. (2011)."Biowastes-to-biofuels,” Energy Conversion and Management, 52, 1815-1828.

Dutta, M. (2004). Cost Accounting: Principles and Practice, Pearson Education, India.

Elms, R.D. and El-Halwagi, M.M. (2010). “The effect of greenhouse gas policy on the design and scheduling of biodiesel plants with multiple feedstocks," Clean Technologies and Environmental Policy, 12, 547560.

Erdmann, E., Ruiz, L.A., Benítez, L and Tarifa, E. (2012). “Análisis de sensibilidad por simulación del proceso de deshidratación de una planta de acondicionamiento de gas natural,” Avances en Ciencias e Ingeniería, 3, 119-130.

Falasca, S.L. and Ulberich, A. (2008). "Potencialidad bioenergética sudamericana a partir de forestaciones con Jatropha sp. (J. curcas, hieronymi y macrocarpa)," Revista Virtual Redesma, 2, 101-116.

Foon, C.S., May, C.Y., Ngan, M.A. and Hock, C.C. (2004). "Kinetic study on transesterification of palm oil,” Journal of Oil Palm Research, 16, 19-29.

Gómez-Castro, F.I., Segovia-Hernandez, J.G., Hernandez, S., Rico-Ramirez, V., Gutierrez-Antonio, C., Briones-Ramirez, A., Cano-Rodriguez, I. and Gamiño-Arroyo, Z. (2015). "Analysis of alternative non-catalytic processes for the production of biodiesel fuel," Clean Technologies and Environmental Policy, 17, 2041-2054.

Granjo, J.F.O., Duarte, B.P.M. and Oliveira, N.M.C. (2017). "Integrated production of biodiesel in a soybean biorefinery:Modeling, simulation and economical assessment”, Energy, 129, 273-291.

Guo, F., Fang, Z., Tian, X.F., Long, Y.D. and Jiang, L.Q. (2011). "One-step production of biodiesel from Jatropha oil with high-acid value in ionic liquids," Bioresource Technology, 102, 6469-6472.

Horngren, C.T., Sundem, G.L. and Stratton, W.O. (2006). Contabilidad Administrativa, Pearson Educación, México.

InfoLEG. (2010). Información Legislativa. Secretaría de Energía. Combustibles. Resolución 828/2010, Especificaciones de calidad del biodiesel. Modifícase la Resolución N 6/10. Ministerio de Justicia y Derechos Humanos, Presidencia de la Nación Argentina. http://servicios.infoleg.gob.ar/ infolegInternet/ anexos/ 170000-174999/171944/norma.htm. Accessed 10 September 2017.

Kapilakarn, K. and Peugtong, A. (2007). “Comparison of costs of biodiesel production from transesterification,” International Energy Journal, 8, 1-6.
Kemp, I.C. (2007). Pinch analysis and process integration: a user guide on process integration for the efficient use of energy, Butterworth-Heinemann, UK.

Kern, D.Q. (1965). Procesos de Transferencia de Calor, Primera Edición, Compañía Editorial Continental SA de CV, México.

Khang, D.S., Tan, R.R., Uy, O.M., Promentilla, A.B., Tuan, P.D., Abe, N. and Razon, L.F. (2018). “A design of experiments approach to the sensitivity analysis of the life cycle cost of biodiesel," Clean Technologies and Environmental Policy, 20, 573-580.

Koh, M.Y. and Ghazi, T.I.M. (2011). “A review of biodiesel production from Jatropha curcas L. oil,” Renewable and Sustainable Energy Reviews, 15, 2240-2251.

Kuo, T.C., Shaw, J.F. and Lee, G.C. (2015). "Conversion of crude Jatropha curcas seed oil into biodiesel using liquid recombinant Candida rugosa lipase isozymes,” Bioresource Technology, 192, 54-59.

Laborde, M.F., Orifici, L.I., Manzur, A.M., Pagano, A.M. and Gely, M.C. (2014 a). "Redes de intercambio de calor aplicadas a la esterificación de aceites vegetales usados," Avances en Ciencias e Ingeniería, 5, 31-44.

Laborde, M.F., Orifici, L.I., Pagano, A.M. and Gely, M.C. (2014b), "Redes de intercambio calórico en la producción de biodiesel a partir de aceites vegetales usados,” Revista Cubana de Ingeniería, 5, 69-78.

Linnhoff, B. and Flower, J.R. (1982). User guide on process integration for the efficient use of energy, Institution of Chemical Engineers Rugby, Warwickshire, UK.

Linnhoff, B. and Hindmarsh, E. (1983). "The Pinch design method for heat exchanger networks," Chemical Engineering Science, 38, 745-763.

López-Díaz, D.C., Lira-Barragan, L.F., Rubio-Castro, E., Serna-Gonzalez, M., El-Halwagi, M.M. and PonceOrtega, J.M. (2018). “Optimization of biofuels production via a water-energy-food nexus framework," Clean Technologies and Environmental Policy, 20, 1443-1466.

Luu, P.D., Truong, H.T., Van Luu, B., Pham, L.N., Imamura, K., Takenaka, N. and Maeda, Y. (2014). "Production of biodiesel from Vietnamese Jatropha curcas oil by a co-solvent method," Bioresource Technology, 173, 309-316.

Marchetti, J.M., Miguel, V.U. and Errazu, A.F. (2008). "Techno-economic study of different alternatives for biodiesel production," Fuel Processing Technology, 89, 740-748.

Morales, W., Polich, N., Sequeira, A., Chamorro E. and Herrero, E. (2010). "Purificación de glicerol obtenido a partir de síntesis de biodiesel de aceite crudo de algodón,” Avances en Energías Renovables y Medio Ambiente, 14, 25-30.

Okullo, A.A., Temu, A.K., Ogwok, P. and Ntalikwa, J.W. (2012). "Physico-chemical properties of biodiesel from Jatropha and castor oils,” International Journal of Renewable Energy Research, 2, 47-52. 
Ong, H.C., Mahalia, T.M.I., Masjuki, H.H. and Norhasyima, R.S. (2011). “Comparison of palm oil, Jatropha curcas and Calophyllum inophyllum for biodiesel: a review," Renewable and Sustainable Energy Reviews, 15, 3501-3515.

Posada Duque, J.A. and Cardona Alzate, C.A. (2010). "Análisis de la refinación de glicerina obtenida como coproducto en la producción de biodiesel," Ingeniería y Universidad, 14, 9-27.

Rajasekaran, V. and Lalitha, R. (2011). Cost Accounting, Pearson Education India (2011).

Ramírez-Verduzco, L.F., Rodríguez-Rodríguez, J.E. and Jaramillo-Jacob, A.d.R. (2012). "Predicting cetane number, kinematic viscosity, density and higher heating value of biodiesel from its fatty acid methyl ester composition,” Fuel, 91, 102-111.

REDPA. (2009). Situación de la Jatropha y Perspectivas. Grupo de trabajo sobre Políticas Públicas en Agroenergía, Red de Coordinación de Políticas Agropecuarias, Consejo Agropecuario del Sur (CAS), http://www.mag.gov.py/ dgp/Situacion\%20y\%20 Perspectivas \%20de\%20la\%20Jatropha\%202009 .pdf. Accessed 10 September 2017.

Renedo Estébanez, C. and Fernández Díez, P. (2003a). “Tecnología pinch para el diseño de redes de intercambiadores (II). Cálculo de la red por encima del pinch,” Ingeniería Química, 403, 210-226.

Renedo Estébanez, C. and Fernández Díez, P. (2003b). “Tecnología pinch para el diseño de redes de intercambiadores (III). Cálculo de la red por debajo del pinch, unión de las dos redes y optimización,” Ingeniería Química, 404, 131-145.

Renner, A., Zelt, T. and Gerteiser, S. (2008). Global market study on Jatropha: Project Inventory: Latin America. London: GEXSI LLP, http://www. jatrophaplatform.org/ Liens/GEXSI\% 20Global \%20Jatropha\%20 Study_CASE\% 20 STUDIES. pdf, 36 p. Accessed 10 September 2017.

Sánchez, E., Ojeda, K., El-Halwagi, M. and Kafarov, V. (2011). "Biodiesel from microalgae oil production in two sequential esterification/transesterifiction reactors: Pinch analysis of heat integration, Chemical Engineering Journal, 176-177, 211-216.

Santacesaria, E., Vicente, G.M., Di Serio, M. and Tesser, R. (2012). "Main technologies in biodiesel production: State of the art and future challenges," Catalysis Today, 195, 2-13.

Teodoro, P.E., Rodrigues, E.V., de Azevedo Peixoto, L., Galvêas Laviola, B. and Lopes Bhering, L. (2017). "Diallel analysis in agronomic traits of Jatropha," Crop Breeding and Applied Biotechnology, 17, 259-265.

Troncoso, F., Gely, C. and Pagano, A.M. (2015). "Refinado industrial de glicerina cruda obtenida en la producción de biodiesel,” Memorias Congreso Latinoamericano Ingeniería y Ciencias Aplicadas, FCAI-UNCuyo, Mendoza, Argentina 12TCQ, 674686.

Ulrich, G.D. and Vasudevan, P.T. (2006). "How to estimate utility costs," Chemical Engineering, 113, 6669.

Ulrich, G.D. and Vasudevan, P.T. (2009). “Capital costs quickly calculated,” Chemical Engineering, 116, 53-60.

West, A.H., Posarac, D. and Ellis, N. (2008). “Assessment of four biodiesel production processes using HYSYS.Plant,” Bioresource Technology, 99, 65876601.

Zhang, Y., Dube, M.A., McLean, D.D.L. and Kates, M. (2003). "Biodiesel production from waste cooking oil: 1. Process design and technological assessment,” Bioresource Technology, 89, 1-16.

Received: July 27, 2018

Sent to Subject Editor: May 9, 2019

Accepted: September 23, 2019

Recommended by Subject Editor: Mariano Martín Martín 